Abstracta Iranica Iranica

Revue bibliographique pour le domaine irano-aryen

Volume 28 | 2007

Comptes rendus des publications de 2005

\title{
In the Rose Garden of the Martyrs: A Memoir of Iran. Harper Collins, 2005, 304 p.
}

\section{Anicée Van Engeland}

\section{(2) OpenEdition}

1 Journals

\section{Édition électronique}

URL : http://journals.openedition.org/abstractairanica/20251

DOI : 10.4000/abstractairanica.20251

ISSN : 1961-960X

Éditeur :

CNRS (UMR 7528 Mondes iraniens et indiens), Éditions de l'IFRI

\section{Édition imprimée}

Date de publication : 15 mai 2007

ISSN : 0240-8910

Référence électronique

Anicée Van Engeland, «In the Rose Garden of the Martyrs: A Memoir of Iran. Harper Collins, 2005,

304 p. », Abstracta Iranica [En ligne], Volume 28 | 2007, document 394, mis en ligne le 18 septembre 2007, consulté le 25 septembre 2020. URL : http://journals.openedition.org/abstractairanica/20251 ; DOI : https://doi.org/10.4000/abstractairanica.20251

Ce document a été généré automatiquement le 25 septembre 2020.

Tous droits réservés 


\title{
In the Rose Garden of the Martyrs: A Memoir of Iran. Harper Collins, 2005, 304 p.
}

\author{
Anicée Van Engeland
}

1 L'A. est un journaliste de The Economist qui a longtemps vécu en Iran. Cet ouvrage fondé sur un travail de terrain est original dans le sens où il mêle histoire, reportage journalistique, mémoires personnelles, journal de voyage, anecdotes et témoignages de membres éminents de la société civile iranienne. Le livre est par conséquent à la fois intime et austère. Des révolutionnaires, héros de la guerre, des vétérans, des intellectuels, des commerçants et des enfants de la révolution s'expriment, mais l'A. parle aussi parfois à la première personne. Il présente toute la complexité de la société iranienne et les difficultés quotidiennes auxquelles fait face la population. Il évoque les fantômes de la guerre avec l'Irak mais aussi les martyrs de la révolution qui planent sur la vie quotidienne des Iraniens. L'ouvrage traite autant la symbolique du martyre que l'élection du président Aḥmadīnežād, les violations des droits de l'homme, le rôle de la société civile, la politique étrangère, l'arme nucléaire et le nationalisme iranien. Outre les descriptions sociales, l'A. recourt aussi à la critique et à l'analyse politique. Le style léger adopté lui permet de passer facilement des entretiens à des critiques fondées sur des anecdotes. Le titre évocateur de l'ouvrage ne fait pas seulement allusion aux nombreux jardins iraniens, lieux de socialisation, mais aussi aux cimetières et plus particulièrement le cimetière iranien qui abrite un grand nombre de morts au combat entre 1980 et 1988. Il décrit l'Iran et propose ainsi aux lecteurs d'accéder à un Iran peu connu et loin des clichés et de l'axe du mal. 
INDEX

Thèmes : 12.1. Iran

\section{AUTEURS}

ANICÉE VAN ENGELAND

Paris 